\title{
The Impact of Managers' Emotional Intelligence on Employees' Work Life Balance: A Field Study at Jordanian Private Hospitals
}

\author{
Dr. Sahar Moh'd Abu Bakir \\ Associate Professor, Business Administration Department, \\ Amman Arab University, Jordan
}

Doi:10.19044/esj.2018.v14n25p256 URL:http://dx.doi.org/10.19044/esj.2018.v14n25p256

\begin{abstract}
This paper focuses on testing the impact of managers' emotional intelligence on employees work life balance in Jordanian private hospitals. 6 out of 13 hospitals were randomly selected, and 300 employees from nonmanagerial levels were surveyed using the questionnaire. 286 questionnaires were also analyzed. The most important findings of the study show that the managers in the examined hospitals have emotional intelligence skills, and the studied hospitals provide their employees with work life balance activities. The results of multiple regression revealed that there is a statistically significant impact of managers' (empathy and social skills) on employees' work life balance. The study revealed that there are differences of respondents' perception of work life balance initiative due to their gender, while there are no differences of employees' perception due to their marital status and number of children. Based on the results, the researcher recommended that more attention should be given to boost managers and employees emotional intelligence skills, and to broaden the scope of the provided work life balance activities in health care organizations and hospitals in particular.
\end{abstract}

Keywords: Emotional Intelligence, Work Life Balance, Jordanian Private Hospitals

\section{INTRODUCTION}

Lately, business organizations are confronting a number of unprecedented challenges; globalization, intense competition, speed and fast response, ethical practices, and social responsibility (Daft, 2010). However, this was accompanied by uncertain (dynamic and complex) external environment (Wheelen \& Hunger, 2013) that makes it more difficult for these organizations, whether manufacturing or services, to survive or prosper (Mathur et al., 2013; Tang \& Gao, 2012). 
According to Avgar et al. (2011) and Singh and Kassa (2016), organizations can face the external obstacles through positive satisfactory internal environment. Johnson et al. (2008) pointed out that the core of organizations internal environment is human resources. Organizations will rely on their competent loyal human resources to achieve the intended objectives together with a sufficient strategic proposition (Kaliannan et al., 2016; Dessler, 2014). The issue is not any more connected with attracting qualifications. Nevertheless, retaining and energizing them to create and perform in outstanding level is a decisive case (Peters et al., 2010). In addition, reducing turnover rate recently represents another challenge to business organizations (Saima \& Zohair, 2016). Gupta (2014) indicated that employees' satisfaction is the key to positive attitudes and actions. Many researchers (Chiva \& Alegre, 2008; Latif et al., 2013; Yadav et al., 2017) confirmed that employees' satisfaction leads to happiness, loyalty, commitment, efficient performance and productivity, plus low turnover rate. Organizations should endeavor never to stop finding satisfaction means, especially based on the fact that diverse human resources make the task more difficult (Robbins \& Judge, 2013). This is in addition to employees' un-similarity reflected in complicating their satisfaction procedures also (Bakir, 2017a).

Lee et al. (2015) and Azeem and Altalhi (2015) commented that achieving balance between job requirements and personal life promotes employees' satisfaction.

Eid (2016) underlined the role of employees' satisfaction in promoting Jordanian hospitals performance.

Goodwin and Richards (2017) discovered that those who are not supported by work- life balance activities recorded high level of dissatisfaction, and their determination to leave the job increased.

Sharma et al. (2016) stated that when employees experience hard working conditions, work life balance initiatives uphold their satisfaction, particularly those who are working at health care organizations mainly hospitals.

Hospitals' employees are specifically exposed to sophisticated conditions; number and type of stressors are different than any other work place. They have to be ready $24 / 7$ for any emergency call (Al-khasawneh \& Moh, 2013). Thus, this is in addition to the sensitivity of the service itself that they provide. Hospitals' employees deal with special type of customers (Mathur et al., 2013). Furthermore, patients need direct medical care and their psychological status necessitates attention (Avgar et al., 2011; Chahal \& Mehta, 2013).

Many thinkers were interested in hospitals employees' needs, and they shed more light on the role of leaders in meeting followers' demands (Lakshmi et al., 2012; Yadav et al., 2017; Mohammad et al., 2011; Parand et al., 2014). 
It also enables them to achieve the right work life balance between work requirements and personal life (Poulose \& Sudarsan, 2017).

Leader's legitimate power is not enough to guarantee employees' involvement and cooperation (Luthans, 2012). Additionally, leader's emotions, spiritual capabilities, and feelings that go beyond the formal roles are critical for a leader's effectiveness (Bakir, 2017b).

Mudra (2016) and Bedi and Kaur (2014) affirmed that work life balance and employees' satisfaction are not an individual issue. As a result, managers are accountable for building a convenient work environment.

Fowlie and Wood (2009) and McCleskey (2014) stated that emotional intelligence (EI) and managers' ability to understand employees' emotions, fears, and problems is vital for creating a comfortable work environment.

Dabke (2016) mentioned that Emotional Intelligence (EI) enables leaders to empower subordinates for better performance. Locke (2009) and Alfonso et al. (2016) proved that managers' Emotional Intelligence (EI) capabilities support employees' positive feelings and boost their ability to get the right balance between family and work duties.

Accordingly, this study has 4 purposes: first, to examine if managers in Jordanian private hospitals have Emotional Intelligence (EI) skills.

The second purpose is to examine if Jordanian private hospitals have work life balance initiatives, and the third is to examine the impact of managers' Emotional Intelligence (EI) on achieving employees' work- life balance. The fourth purpose is to test if there are any differences in employees' perception of work life balance initiatives due to their Gender, marital status, and number of children.

\section{THE STUDY'S PROBLEM}

Private hospitals in Jordan face the same challenges as other business organizations. They had to survive and remain competitive in a changing environment. As the number of health providers increased, all hospitals are competing to attract patients through providing better services. This is dependent mainly on qualified employees and on the employees' readiness to perform better than their peers in other hospitals. Meanwhile, it is not easy to stimulate unsatisfied employees to be excellent. Hospitals' staff experiences numerous difficulties which is essential in their attempts to get the balance between job requirements and personal life.

Makabe et al. (2015), Kumar and Chakraborty (2013), and Rama and Nagini (2014) proved that work life balance is an essential factor for employees' satisfaction in the health sector.

Consequently, managers are obliged to find solutions. Emotional Intelligence (EI) skills help to put employees in the right path, and broaden the 
perception of employees' problems, particularly the conflict between life burden inside the hospital and outside.

Accordingly, the researcher is trying, through this study, to answer the following questions:

1. Do managers in Jordanian private hospitals have Emotional Intelligence (EI) Skills?

2. Do Jordanian private hospitals have work life balance initiatives?

3. What is the impact of managers' Emotional Intelligence (EI) skills in achieving employees' work life balance?

4. Are there any differences in employees' perception of work life balance initiatives due to their Gender, marital status, and number of children?

\section{STUDY'S HYPOTHESES AND MODEL}

H1: Managers in Jordanian Private Hospitals have emotional intelligence skills.

H2: Jordanian Private Hospitals have work life balance initiatives.

H3: Managers' emotional intelligence (self-awareness, selfmanagement, self-motivation, empathy, and social skills) positively affect employees' work life balance.

H4: There are statistically significant differences in employees' perception of work life balance initiatives due to demographic characteristics (Gender, marital status, and number of children).

Independent Variable/s

Dependent variable

Emotional Intelligence

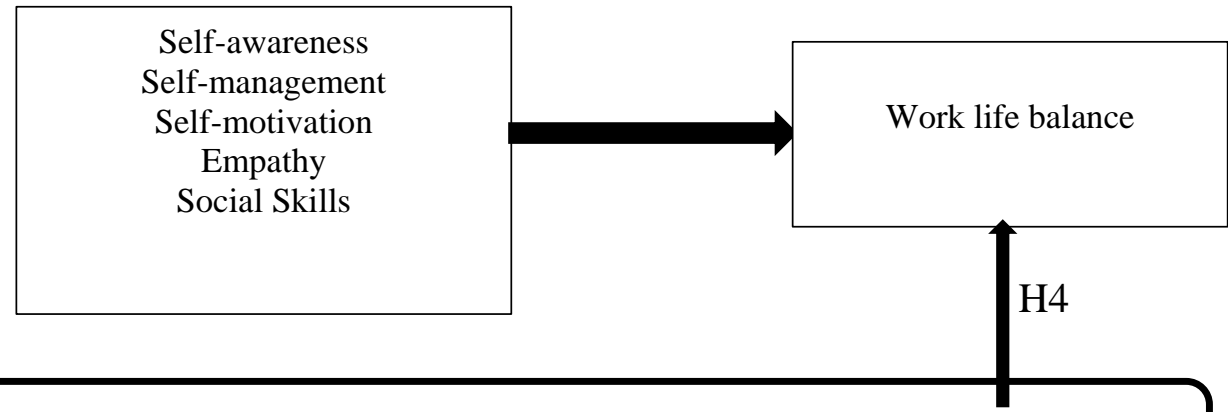

Demographic characteristics (gender, marital status, and number of children

\section{LITERATURE REVIEW AND THEORETICAL BACKGROUND 4.1. Emotional Intelligence (EI)}

Emotional intelligence as a concept have attracted the attention of psychologists many years ago, and it has developed step by step to become one of the basic subjects in organizations' behavior and leadership (Chiva \& 
Alegre, 2008), particularly in people-centered organizations (Armstrong, 2006).

According to Dabke (2016), Emotional Intelligence (EI) began in the year 1920; thus, this was when Thorndike considered the social intelligence as a critical source of people's success.

McCleskey (2014) illustrated that after 1920, the term used to express individuals' interpersonal and intrapersonal skills was compatible with Gardner theory of multiple intelligence. This theory stated that individual's promotion depends on more than his/ her IQ, social skills and the ability to understand ones and others feelings, emotions, motivations, and fears are important too (Asiamah, 2017).

Salehi et al. (2016) declared that Emotional Intelligence (EI) is not separated from IQ, but both can be used smartly in work place. Emotions are responsible for $80 \%$ of employees' success, while just $20 \%$ is attributed to IQ.

\subsubsection{Emotional Intelligence (EI) Models and Constitutions}

Robbins and Judge (2013) argued that Emotional Intelligence (EI) constitutions have a sequential form. Mostly all Emotional Intelligence (EI) models started with realizing feelings and emotions of one's self and others, and understanding the content of these feelings and emotions to be able to take actions accordingly (Armstrong, 2006). The ability-based model, for example, proposed four dimensions of Emotional Intelligence (EI); the first is Emotional Perception, followed by Emotional Understanding, the third is Emotional Use, and the fourth dimension is Emotional Management (Daus \& Ashkanasy, 2005).

Meanwhile, the most popular model is the five dimensions model which was developed by Goleman (1998). This model expressed the complementary pattern of managing self and others' emotions (Torrington et al., 2011).

Golemans' model comprised of three (3) self-dimensions (selfawareness, self-management, self-motivation) and it also deals with others two (2) dimensions (empathy and social skills) (Dessler, 2014; Alfonso et al., 2016).

The First and the Prerequisite of Other Dimensions is Self-Awareness

This is the corner stone of Emotional Intelligence (EI) (Hopkins \& Yonker, 2015). It can be expressed by the individual's ability to understand his/her feelings, moods, emotions, and their drives (Robbins \& Judge, 2013). It also helps them to identify their weakness and strengths in order to avoid weakness and take advantage of their strengths to have a significant impact on others (Jiang, 2014).

The second dimension is Self-management or (Self- Regulation). 
Stubbs and Wolff (2008) articulated that self-management will not be achieved without self-awareness. Those who recorded levels of selfmanagement have the ability to control and direct their moods and feelings (to think before acting).

Luthans (2012) opined that in self-management, the individual get rid of unfavorable feelings that is capable to have a means of controlling anger and disruptive emotions.

McKeown and Bates (2013) pointed that persons who are characterized by self-management are trustworthy in achieving good levels of integrity; they are conscientiously responsible for personal performance and fulfillment of obligations. In addition, they are able to adapt and possess means of flexibility in the face of change as stated by Santos et al. (2015).

The third dimension is Self-motivation.

However, those with high self-motivation can easily determine their objectives (Gibson et al., 2012). They can stimulate their interior courage to achieve their own aims, realize (beyond money and status) their achievement motivators, and are also able to mobilize others to attain their goals and objectives (Lam \& O’Higgins, 2012).

According to Zhang et al. (2015), people with self-motivation are innovators and success seekers.

The next two dimensions (empathy and social skills) relied on the individual's proficiency in interacting successfully with others (Robbins \& Judge, 2013).

Empathy (social awareness) is linked with the ability to comprehend others' feelings and emotions and act accordingly (Gibson et al., 2012). In spite of the intersection between sympathy and empathy, the two concepts are not the same, but they are both indispensable to have Emotional Intelligence (EI) skills. The first makes the individual feel bad in regards to the suffering of others, while the second gives him/ her the potency to provide assistance and support (Alfonso et al., 2016).

Shafiq and RANA (2016) perceived empathy as a tool for creating a healthy atmosphere inside organizations.

Social skills are the fifth dimension.

It involves constructing positive links, strengthening mutually beneficial relationships with others, and inspiring a climate of harmony among organization's members (Chiva \& Alegre, 2008).

Those with social skills possess communication and listening skills, work within team spirit, and can easily achieve group objectives (Stubbs \& Wolff, 2008). 


\subsubsection{Benefits of Emotional Intelligence (EI)}

Long et al. (2016) argued that EI is more pivotal in services organizations, particularly when quality level is associated with the service itself. In their research, they concluded that Emotional Intelligence (EI) enables individuals to interact in a constructive manner with colleagues, subordinates, managers, and with customers also. Bedi and Kaur (2014) revealed that Emotional Intelligence (EI) enhances employees' positive perception of work environment and promotes their job satisfaction.

Shafiq and RANA (2016) results asserted that Emotional Intelligence (EI) reinforces Pakistanis college teachers' capabilities to understand students, to be tolerant, patient, control their temper and the most important able to handle the conflict between life and job requirements in a balanced manner. According to Torrington et al. (2011), those with Emotional Intelligence (EI) skills are able to overcome problems that resulted from uncertainty and ambiguity in the work place.

Tang and Gao (2012) proved that those with Emotional Intelligence (EI) are eager to be involved in organizational change rather than being neutral, or resist change.

At work team level, Ghosh et al. (2012) indicated that Emotional Intelligence (EI) empowers team members to set collective objectives, and design the right means of obtaining the intended results.

However, Hopkins and Yonker (2015) referred that Emotional Intelligence (EI) minimizes disagreements and conflict among team members and it supports team cohesion. Clarke (2010) underlined the impact of Emotional Intelligence (EI) in achieving a sufficient level of synergy between team members, and it also has a positive influence on team outcomes.

Stubbs and Wolff (2008) pointed out that Emotional Intelligence (EI) facilitates valued interaction among team members and promotes learning from each other. Meanwhile, Arfara and Samanta (2016) clarified that Emotional Intelligence (EI) instilled mutual trust and reinforced team members knowledge sharing. Bedi and Kaur (2014) findings show that Emotional Intelligence (EI) fosters individuals' work life balance.

At the leadership and managers level, the results obtained by the study of Hui-Wen et al. (2010) and Salehi et al. (2016) indicated that Emotional Intelligence (EI) ingenuity is substantial for leadership success. Therefore, Emotional Intelligence (EI) is considered as one of the basic characteristics leaders must have in any profession.

The study of Jiang (2014) stated that managers with Emotional Intelligence (EI) proficiencies are able to convince others easily and utilize their influence to gain subordinates' voluntary compliance.

Torrington et al. (2011) added that Emotional Intelligence (EI) skills distinguish the leader managers from non-leaders. 


\subsection{Work Life Balance (WLB)}

Work life balance stems from the fact that employees have multiple responsibilities at work and at their personal life (Robbins \& Judge, 2013; Haar et al., 2014).

The limitation of available time and resources led to a state of contradiction of employees' obligations (Pandita \& Singhal, 2017). The overload resulted in unpleasant consequences on the life of the employees, Job stress, depression, and sometimes burnout (Kaliannan et al., 2016; Jamal, 2013). However, the most serious negative impacts of work life imbalance are in regards to employees' performance level and their turnover rate (Hughes \& Bozionelos, 2007). It was proved that employees' efficiency, productivity, their loyalty, and their organizational commitment decreased with the state of imbalance, and their intention to leave work increased (Locke, 2009). Accordingly, organizations realized that work life balance problem goes beyond employees' level as managers are involved too (Avgar et al., 2011). Managers had to utilize their capabilities, talents, communication skills, and their formal authority to solve employees' work life balance dilemma (Borah \& Bagl, 2016). The proposed initiatives exceed short term actions, while WLB objectives were recently promoted to be part of organizations' mission and its main strategies (Khan \& Agha, 2013).

\subsubsection{Work Life Balance (WLB) Initiatives}

WLB initiatives had two themes; the first described organizations' support activities, and management's endeavors to assist employees in allocating their available time, energy, and efforts between work duties and other aspects in life (Saima \& Zohair, 2016; Sharma et al., 2016). The objective is to enable employees to have time for job tasks fulfillment in addition to family, friends and social life and, above all, for him/ herself (Tanushree, 2013). Torrington et al. (2011) mentioned that in its beginnings, work life balance actions was introduced in the form of maternity leaves and other related leaves before and after giving birth, as a clue of organizational compliance to working women rights. Later, the scope and number of leaves extended to encompass parental leave, childcare leave, sick leave, etc.

Consequently, organizations have started to offer childcare options whether by establishing a childcare center within the workplace, or by paying childcare allowance (Yang et al., 2017).

Recently, organizations are engaged also in various set of practices such as Telecommuting, where employees are ready to spend more time working from home especially when there are children and or old persons who need continuous care (Poulose \& Sudarsan, 2017). They can complete all the required tasks using information technology from places other than the office (Mudra, 2016). Flexible working hours is another proposition, especially in 
24/7 services organizations e.g. hospitals and hospitality firms (Khan \& Agha, 2013). WLB interventions can also include managing stress training courses to enhance employees' adaptation capabilities, in addition to special consultation by management or specialists (Sharma et al., 2016).

The second theme was connected with researcher's interest to examine the relationship between employees' demographic characteristics and their perception and satisfaction of work life balance initiatives. Gender perception had the largest portion based on the researchers concern e.g. Emslie and Hunt (2009); Doble and Supriya (2010); Fujimoto et al. (2013); Kakkar and Bhandari (2016).

Meanwhile, Rehman and Azam (2012) were more interested in female entrepreneurs and the difficulties they face, especially when startups stand on a long time and hard efforts devotion.

In their study, Ciarniene and Vienazindiene (2018) aimed to check the differences due to age in regards to flexible working hours and their expectations of work life balance activities.

Amazue and Onyishi (2016), Devi and Sheshadri (2016), and Jailaxmi and Gautam (2017) were interested in marital status and its impact on work life balance perception and achievements.

\subsubsection{Work Life Balance Yields}

Recently, WLB movements are treated as a long term investment. Thus, there is no doubt that a minimum of three parties (employees, organizations and families) are getting benefit from WLB initiatives (Armstrong, 2006).

First: Employees who have work-life balance feel their objectives were attained inside work and at their social life. They undergoes less contradiction between work and non-work duties (Haar et al., 2014). In addition, they have higher levels of gratification either with their jobs and life, as well as lower levels of pressure and depression (Kaliannan et al., 2016).

Kumarasamy et al. (2016) findings underlined the significance of work life balance in avoiding many physical and psychological problems employees might confront.

Rama and Nagini (2014) found an inverse relationship between employees' work life balance and burnout.

Second: Organizations are not away from WLB actions' positive outcomes. Makabe et al. (2015) conducted their research at 3 Japanese hospitals and found that work life balance is an energizer not only for better productivity, but also for attracting and retaining qualifications, and reducing turnover rate especially among nursing staff. 
Avgar et al. (2011) examined the direct and indirect consequences of achieving work life balance. They deduced that work life balance in hospitals is critical for providing high level of patient care.

Kim (2014) conclusions underlined work life balance value in instilling positive attitudes, citizenship behavior, and organizational commitment. According to Kumar and Chakraborty (2013), WLB reduces workers absenteeism and minimizes work stoppage and delivery delay.

Third: Family is the third element that benefits from WLB practices. Sharma et al. (2016) illustrated that family requirements are accomplished in a satisfactory manner in terms of time devotion, efforts, and care.

\subsection{Emotional Intelligence and Work Life Balance}

Many previous studies explored the relationship between persons' emotional intelligence and their work life balance achievements.

Thorat and Dharwadkar (2016) found that EI enabled banking sector employees to obtain an appropriate level of work life balance.

Depending on a survey of 55 workers, from different ages and different careers, Sharma (2014) confirmed the positive link between EI and WLB.

Srividhya and Sharmila (2014) inferred that EI skills enabled Indian working women to handle both family and work duties efficiently.

Furthermore, the findings of Kumarasamy et al. (2016) gave light on managers' EI contribution in fostering employees' work life balance.

Koubova and Buchko (2013) and Shylaja and Prasad (2017) agreed with others that achieving work life balance is not easy for employees alone; managers EI proficiency facilitates realizing employees conflicting feelings and roles; and Emotional Intelligence (EI) skills enable managers to set convenient strategies for attaining employees work life balance.

\section{STUDY'S METHODOLOGY}

\subsection{Study's Population and Sample}

Jordanian private hospitals operating at the capital, Amman, were targeted as the study's population. 6 out of 13 hospitals accepted to be part of the survey. 300 employees working at the non-managerial level were involved and selected randomly from the 3 shifts, $\mathrm{A}, \mathrm{B}$, and $\mathrm{C}$.

$64.7 \%$ of them are males, while $35.3 \%$ females. $19.5 \%$ have a diploma degree, $73.2 \%$ have bachelor degree, and $7.3 \%$ have a master degree. Their work experiences in hospitals were as follows: $21.8 \%$ of them have less than 3 years' work experience, $39.4 \%$ of them have $3-5$ years, and $38.8 \%$ of them have more than 5 years' experience.

They were between $25-45$ years old. $68.1 \%$ of them were married, $31.9 \%$ were un-married,

$75 \%$ of the married employees had at least one child. 


\subsection{Study's Measures and Tools}

To collect the required information and data, the researcher depended on a questionnaire that contains a group of questions distributed as follows: the first part was related to the sampling unit's information (gender, experience, education, age, marital status, and number of children).

However, the other two (2) parts used likert five scale of acceptance ranging from 1 "high disagreed" to 5 "high level of agreement".

The second part contains 25 questions utilized to measure the independent variable (Emotional intelligence). The researcher relied on Goleman's (1998) five (5) dimensions (self-awareness, self-management, self-motivation, empathy and social skills). Goleman stated that EI includes five dimensions and 25 subcompetencies (Luthans, 2012). Therefore, the researcher developed 5 questions for each dimension.

The third part of the questionnaire consisted of questions employed to measure the dependent variable (Work life balance).

Referring to what was introduced in the literature and in previous studies, work life balance was measured using 10 questions concerning formal and informal supportive activities provided by managers to help employees in making decisions, in setting priorities, and in organizing time between family and job obligations.

300 questionnaires were distributed and returned back by hand, 14 questionnaires weren't, properly filled, and accordingly 286 were statistically analyzed.

\section{STATISTICAL ANALYSIS RESULTS \\ 6.1. Questionnaire's Validity and Reliability}

The researcher tested the face validity of the questionnaire, according to Sekaran (2003). Face validity checks the ability of the questionnaire to measure what is aimed to measure, and the degree to which the questionnaire reflects adequately the variables under considerations. For this study's purpose, the questionnaire was revised by a group of instructors specialized in human resources management. However, based on their suggestions, the questionnaire was modified.

Meanwhile, reliability is connected with internal consistency and the relationship of the questions that measure each variable with each other.

It measures the robustness of the questionnaire and the possibility of getting harmonious results if the survey is repeated (Zikmund, 2003).

As Saunders et al. (2009) commented, there is consent that Cronbach's alpha is the most used measure of internal consistency.

Therefore, Cronbach's alpha was estimated for all variables. The results in Table 1 shows that all the values of Cronbach's alpha are larger than $70 \%$. In accordance to Sekaran (2003), the tool used is reliable. 
Table 1. Cronbach's alpha results

\begin{tabular}{|c|c|c|c|}
\hline Variable/ s & Cronbach's alpha & Variable/ s & Cronbach's alpha \\
\hline Self-awareness & 0.78 & Empathy & 0.79 \\
\hline Self-management & 0.81 & Social skills & 0.86 \\
\hline Self-motivation & 0.84 & Work- life balance & 0.76 \\
\hline
\end{tabular}

\subsection{The Results of Descriptive Statistics}

Arithmetic mean and standard deviation were calculated for all questionnaire questions. The numbers in Table 2 exhibit the total means of emotional intelligence elements, presented in a descending order, and the total mean of WLB questions.

The displayed means which are all above 3 as the threshold, indicated that the surveyed employees view their managers as having Emotional Intelligence (EI) skills, and they are provided by WLB.

Table 2. Descriptive statistics results / $\mathrm{N}=\mathbf{2 8 6}$

\begin{tabular}{|l|c|c|}
\hline Study Variables & Number of Questions & Total Arithmetic Means \\
\hline Emotional Intelligence & 5 & 4.1769 \\
Social skills & 5 & 4.1340 \\
Empathy & 5 & 4.0937 \\
Self-motivation & 5 & 3.7290 \\
Self-management & 5 & 3.6300 \\
Self-awareness & 10 & 3.9167 \\
Work life balance initiatives & 5 & \\
\hline
\end{tabular}

\subsection{Testing Hypotheses}

For testing the first and the second hypotheses, one sample t test was used. The rule for hypotheses' acceptance will be as follows:

The hypothesis will be accepted if $t$ sig level is less than $p$ value which is 0.05 , and this will be rejected in case $t$ sig level is greater than 0.05 .

\section{H1 Results}

Table 3. One-Sample $T$ test for the first hypothesis

\begin{tabular}{|c|c|c|c|c|c|c|}
\hline \multirow{3}{*}{$\begin{array}{l}\text { Emotional } \\
\text { Intelligence } \\
\text { Elements }\end{array}$} & \multicolumn{6}{|c|}{ Test Value $=3$} \\
\hline & \multirow{2}{*}{$\begin{array}{c}\mathbf{T} \\
\text { Calculate } \\
\mathbf{d}\end{array}$} & \multirow[t]{2}{*}{ D f } & \multirow[t]{2}{*}{ Sig. (2-tailed) } & \multirow[t]{2}{*}{$\begin{array}{c}\text { Mean } \\
\text { Difference }\end{array}$} & \multicolumn{2}{|c|}{$\begin{array}{l}95 \% \text { Confidence Interval of } \\
\text { the Difference }\end{array}$} \\
\hline & & & & & Lower & Upper \\
\hline Social skills & 33.920 & 285 & .000 & 1.17692 & 1.1086 & 1.2452 \\
\hline Empathy & 34.196 & 285 & .000 & 1.13403 & 1.0688 & 1.1993 \\
\hline Self-motivation & 26.046 & 285 & .000 & 1.09371 & 1.0111 & 1.1764 \\
\hline Self-management & 14.188 & 285 & .000 & .72902 & .6279 & .8302 \\
\hline Self-awareness & 10.961 & 285 & .000 & 62995 & .5168 & .7431 \\
\hline
\end{tabular}

Table 3 shows that $t$ sig levels of all Emotional Intelligence (EI) elements are less than $\mathrm{p}$ value 0.05 , and all the calculated values of $t$ are greater than its tabulated value (1.962) at 0.95 confidence, and (n-1) (285) (df) degrees of freedom. 
Relying on the above mentioned rule, the hypothesis will be accepted. This indicated that managers are perceived positively by their subordinates.

The respondents consider their managers to possess emotional intelligence potencies. The results in Table 2 and 3 proved that Jordanian private hospitals managers have sufficient level of social skills, building good relationship, and effective interaction with employees. They also have problem solving and persuading skills and a high level of empathy. They understand their employees' feelings and suffering, and act with empathy to lessen the negative consequences of job stress. At the same time, they are able to energize themselves to achieve their own objectives and the organizations' objectives, and motivate their employees to build up and achieve individual objectives.

\section{H2 Results}

Table 4. One sample $T$ test for the second hypothesis

\begin{tabular}{|c|c|c|c|c|c|c|}
\hline \multirow{4}{*}{$\begin{array}{l}\text { Work } \\
\text { Life } \\
\text { Balance }\end{array}$} & \multicolumn{6}{|c|}{ Test Value $=3$} \\
\hline & \multirow[t]{2}{*}{$\mathbf{t}$} & \multirow[t]{2}{*}{ D f } & \multirow[t]{2}{*}{ Sig. (2-tailed) } & \multirow[t]{2}{*}{$\begin{array}{c}\text { Mean } \\
\text { Difference }\end{array}$} & \multicolumn{2}{|c|}{$\begin{array}{l}\text { 95\% Confidence Interval of the } \\
\text { Difference }\end{array}$} \\
\hline & & & & & Lower & Upper \\
\hline & 26.312 & 285 & .000 & .91667 & .8481 & .9852 \\
\hline
\end{tabular}

Table 4 demonstrates the following:

$\mathrm{T}$ sig level of work life balance initiatives $=0.000$, and it is less than $\mathrm{p}$ value 0.05 ,

T calculated value (26.312) which is greater than its tabulated value at 0.95 confidence, and $285(\mathrm{df})$, which $=1.962$. Relying on the mentioned results, hypothesis 2 will be accepted. The results signalized that the surveyed hospitals have work life balance initiatives, in terms of the application of flexible working hours, child care programs, provision of the necessary help to the employees to set their schedule, and to prioritize their duties in a satisfactory manner.

\section{H3 Results}

Multiple regression were calculated to test the third hypothesis. The decisions concerning this hypothesis results will stand on the following rules:

1. The model will be treated to be suitable to test the regression, and the relationship between the variables will be considered linear, if ( $\mathrm{F}$ calculated) sig value is less than $\mathrm{p}$ value $(0.05)$;

2. The hypothesis will be accepted if $T$ calculated sig value is less than $p$ value (0.05) (Saunders et al., 2009).

Table 5 exhibits the results of ANOVA, the model summary, and the coefficients of hypothesis 3 . The table shows that the correlation value $\mathrm{R}=.501$, which indicated that there is a moderate statistically positive association between managers emotional intelligence and employees perception of work life balance. 
$\mathrm{R}^{2}$ value $=.251$ according to Sekaran (2003). The value of $\mathrm{R}^{2}$ represents the percentage of change in the dependent variable that is explained by the independent variable. However, this means in the obtained result that $25.1 \%$ of the variation in work life balance achievement is due to managers' emotional intelligence.

Table 5 also displays $F$ calculated value, which $=18.732$ at 0.000 . This result articulates that the model is accepted for the regression test, and the relation between the two (2) main variables is linear.

The value of F sig (0.000) also inferred that at least one of the tested sub independent variables has a significant impact on employees work life balance.

Table 5. Multiple regression results of $\mathrm{H3}$

\begin{tabular}{|c|c|c|c|c|}
\hline \multicolumn{5}{|c|}{ ANOVA \& Model Summary Results } \\
\hline $\mathbf{F}$ & F sig & Adjusted $\mathbf{R}^{2}$ & $\mathbf{R}$ & $\mathbf{R}^{2}$ \\
\hline 18.732 & 0.000 & 0.237 & 0.501 & 0.251 \\
\hline \multicolumn{5}{|c|}{ Coefficients } \\
\hline $\begin{array}{l}\text { Independent } \\
\text { Variables }\end{array}$ & B & Beta & $\mathbf{T}$ & T sig \\
\hline Self-awareness & .196 & .324 & .868 & .386 \\
\hline Self-management & -.014 & -.021 & -.053 & .958 \\
\hline Self-motivation & .006 & .007 & .101 & .920 \\
\hline Empathy & .135 & .129 & 2.098 & .037 \\
\hline Social Skills & .214 & .213 & 3.624 & .000 \\
\hline
\end{tabular}

The values of $\mathrm{t}$ sig for Emotional Intelligence (EI) dimensions were as follows: Self-awareness (.386), self-management (.958), self- motivation (.920), empathy (.037), and social skills (0.000).

Depending on the previously mentioned rule, the results indicated that there is no statistically significant impact of self-awareness, self-management, and self-motivation on work life balance due to their sig values which are > 0.05 .

Furthermore, the results show that the two dimensions, empathy and social skills, both have a statistically significant impact on the work- life balance due to their $\mathrm{t}$ sig which are less than 0.05 . This influence is confirmed by the standardized coefficient Beta values, which $=12.9 \%$ and $21.3 \%$ respectively. According to Nathans et al. (2012), Beta value illustrates the effect that each independent variable has on the dependent variable, which provides researchers a base for comparing between independent variables effect.

\section{H4 Results}

To test the fourth hypothesis, independent samples t test at 0.05 value was used.

Zikmund (2003) stated that this mechanism is applied to test the differences of two groups' means. 
Taking into consideration that the degrees of freedom $=\mathrm{n}-\mathrm{k}$

$\mathrm{n}=\mathrm{n} 1+\mathrm{n} 2$

$\mathrm{n} 1$ : is the sample size of group 1

$\mathrm{n} 2$ : is the sample size of group 2

$\mathrm{K}=$ number of groups,

For this study, they are two groups, and respondents are classified due to their demographic characteristics as follows:

1. Gender (male, female)

2. Marital status (Married and not married)

3. Number of children (having at least one child, and don't have children)

The decisions of testing the fourth hypothesis relied on what Sekaran (2003) illustrated; "the decision of variables variances equality will depend on Levene's Test and specifically on F sig value if it is $>(0.05)$." From the other side, the two groups variances will be considered different (unequal) if $\mathrm{F}$ sig value $<0.05$.

On the other hand, the means of the two groups responses will be considered equal if $\mathrm{t}$ sig level is higher than $\mathrm{p}(0.05)$.

First: The results of testing the differences in employees' perception of work life balance initiatives due to Gender.

Table 6 displays the results of the first demographic factor (Gender).

The table shows males and females numbers, $\mathrm{n} 1$ and $\mathrm{n} 2(185,101)$, in addition to the arithmetic means of the two groups responses $(3.80,3.98)$ respectively.

Table 6. Group Statistics of Gender

\begin{tabular}{|c|c|c|c|c|}
\hline Gender & $\mathrm{N}$ & Mean & Std. Deviation & Std. Error Mean \\
\hline Male & 185 & 3.8003 & .56804 & .04176 \\
Female & 101 & 3.9802 & .61193 & .06089 \\
\hline
\end{tabular}

While Table 7 displays Levene's Test for variances equality which encompasses the value of F (2.984) and F sig (0.08) which is greater than 0.05, these values indicated that the variances of males and females responses are equal.

Table 7 also displays the results of $\mathrm{t} \operatorname{sig}=(0.013)$ which is $<0.05$.

Based on the above mentioned rule, it is inferred (means inequality) that there is a statistically significant difference between females and males perception of work life balance initiatives that are provided by their organizations. 
Table 7. Independent samples t test (differences due to gender)

\begin{tabular}{|c|c|c|c|c|c|c|c|c|c|}
\hline \multirow{3}{*}{$\begin{array}{l}\text { Work life } \\
\text { balance } \\
\text { perception } \\
\text { differences } \\
\text { due to } \\
\text { Gender }\end{array}$} & \multicolumn{2}{|c|}{$\begin{array}{c}\text { Levene's Test } \\
\text { for Equality } \\
\text { of Variances }\end{array}$} & \multicolumn{7}{|c|}{ t-test for Equality of Means } \\
\hline & \multirow[t]{2}{*}{$\mathrm{F}$} & \multirow[t]{2}{*}{ Sig. } & \multirow[t]{2}{*}{$\mathrm{t}$} & \multirow[t]{2}{*}{ df } & \multirow[t]{2}{*}{$\begin{array}{l}\text { Sig. } \\
(2- \\
\text { tailed })\end{array}$} & \multirow[t]{2}{*}{$\begin{array}{c}\text { Mean } \\
\text { Difference }\end{array}$} & \multirow[t]{2}{*}{$\begin{array}{l}\text { Std. Error } \\
\text { Difference }\end{array}$} & \multicolumn{2}{|c|}{$\begin{array}{l}\text { 95\% Confidence } \\
\text { Interval of the } \\
\text { Difference }\end{array}$} \\
\hline & & & & & & & & Lower & Upper \\
\hline $\begin{array}{c}\text { Equal } \\
\text { variances } \\
\text { assumed }\end{array}$ & 2.984 & .085 & 2.490 & 284 & .013 & .17985 & .07224 & .03766 & .32204 \\
\hline $\begin{array}{c}\text { Equal } \\
\text { variances } \\
\text { not } \\
\text { assumed }\end{array}$ & & & 2.436 & 193.006 & .016 & .17985 & .07384 & .03422 & .32548 \\
\hline
\end{tabular}

Second: The results of testing the differences in employees' perception of work life balance initiatives due to marital status.

Table 8 shows that 91 of the respondents are unmarried, while 195 are married. The table presents also the mean of the unmarried employees responses which $=3.9046$ and the mean of married employees responses which $=3.985$.

Table 8. Group Statistics of marital status

\begin{tabular}{|l|c|c|c|c|}
\hline \multicolumn{1}{|c|}{ Marital Status } & $\mathrm{N}$ & Mean & Std. Deviation & Std. Error Mean \\
\hline Un- & 91 & 3.9046 & .56254 & .05897 \\
married & 195 & 3.9853 & .59992 & .04296 \\
Married & & & \\
\hline
\end{tabular}

According to Table 9, the value of $\mathrm{F}$ sig $=0.383$, which is $>0.05$, indicated that there are no differences between married and unmarried responses variances.

Meanwhile, the value of $\mathrm{t}$ sig $=.179$, which is $>0.05$, inferred ( means equality) that there are no statistically significant differences between the means of married and unmarried employees perception of work life balance initiatives. 
Table 9. Independent samples t test (differences due to marital status)

\begin{tabular}{|c|c|c|c|c|c|c|c|c|c|}
\hline \multirow{3}{*}{$\begin{array}{l}\text { Work life } \\
\text { balance } \\
\text { perception } \\
\text { differences } \\
\text { due to } \\
\text { marital } \\
\text { status }\end{array}$} & \multicolumn{2}{|c|}{$\begin{array}{l}\text { Levene's } \\
\text { Test for } \\
\text { Equality } \\
\text { of } \\
\text { Variances }\end{array}$} & \multicolumn{7}{|c|}{ t-test for Equality of Means } \\
\hline & \multirow[t]{2}{*}{$\mathrm{F}$} & \multirow[t]{2}{*}{ Sig. } & \multirow[t]{2}{*}{$\mathrm{t}$} & \multirow[t]{2}{*}{ df } & \multirow[t]{2}{*}{$\begin{array}{l}\text { Sig. } \\
(2- \\
\text { tailed })\end{array}$} & \multirow[t]{2}{*}{$\begin{array}{c}\text { Mean } \\
\text { Difference }\end{array}$} & \multirow[t]{2}{*}{$\begin{array}{l}\text { Std. Error } \\
\text { Difference }\end{array}$} & \multicolumn{2}{|c|}{$\begin{array}{c}\text { 95\% Confidence } \\
\text { Interval of the } \\
\text { Difference }\end{array}$} \\
\hline & & & & & & & & Lower & Upper \\
\hline $\begin{array}{c}\text { Equal } \\
\text { variances } \\
\text { assumed } \\
\end{array}$ & .762 & .383 & 1.349 & 284 & .179 & .10073 & .07469 & -.04628 & .24775 \\
\hline $\begin{array}{c}\text { Equal } \\
\text { variances } \\
\text { not } \\
\text { assumed }\end{array}$ & & & 1.381 & & .169 & .10073 & .07296 & -.04320 & .24466 \\
\hline
\end{tabular}

Third: The results of testing the differences in employees' perception of work life balance initiatives due to number of children.

Table 10 manifests that out of the 195 married respondents, 146 have at least one child, while 49 have no children.

Table 10. Group Statistics of number of children

\begin{tabular}{|r|c|c|c|c|}
\hline Number of Children & $\mathrm{N}$ & Mean & Std. Deviation & Std. Error Mean \\
\hline $\begin{array}{c}\text { At least one } \\
\text { child }\end{array}$ & 146 & 4.0340 & .61635 & .05101 \\
No children & 49 & 3.8527 & .59898 & .08557 \\
\hline
\end{tabular}

Table 11 shows equal variances of the two groups responses based on the value of $\mathrm{F}$ ( $\mathrm{sig}) .195$ which is $>0.05$.

Furthermore, the value of $\mathrm{t}$ sig (0.074), which is $>0.05$, shows that there are no statistically significant differences in the means of respondents' perception of work life balance initiatives due to the number of children.

Table 11. Independent samples $t$ test (differences due to number of children)

\begin{tabular}{|c|c|c|c|c|c|c|c|c|c|}
\hline \multirow{3}{*}{$\begin{array}{l}\text { Work life } \\
\text { balance } \\
\text { perception } \\
\text { differences due } \\
\text { to the number } \\
\text { of children }\end{array}$} & \multicolumn{2}{|c|}{$\begin{array}{l}\text { Levene's } \\
\text { Test for } \\
\text { Equality of } \\
\text { Variances } \\
\end{array}$} & \multicolumn{7}{|c|}{ t-test for Equality of Means } \\
\hline & \multirow[t]{2}{*}{$\mathrm{F}$} & \multirow[t]{2}{*}{ Sig. } & \multirow[t]{2}{*}{$\mathrm{t}$} & \multirow[t]{2}{*}{$\mathrm{df}$} & \multirow[t]{2}{*}{$\begin{array}{l}\text { Sig. } \\
(2- \\
\text { tailed })\end{array}$} & \multirow[t]{2}{*}{$\begin{array}{c}\text { Mean } \\
\text { Difference }\end{array}$} & \multirow[t]{2}{*}{$\begin{array}{l}\text { Std. Error } \\
\text { Difference }\end{array}$} & \multicolumn{2}{|c|}{$\begin{array}{l}95 \% \text { Confidence } \\
\text { Interval of the } \\
\text { Difference }\end{array}$} \\
\hline & & & & & & & & Lower & Upper \\
\hline $\begin{array}{l}\text { Equal variances } \\
\text { assumed }\end{array}$ & 1.694 & .195 & $\begin{array}{c}- \\
1.794\end{array}$ & 193 & .074 & -.18127 & .10105 & -.38058 & .01804 \\
\hline $\begin{array}{l}\text { Equal variances } \\
\text { not assumed }\end{array}$ & & & $\begin{array}{c}- \\
1.820\end{array}$ & & .072 & -.18127 & .09962 & -.37935 & .01681 \\
\hline
\end{tabular}




\section{DISCUSSION, IMPLICATIONS AND RECOMMENDATIONS}

It was fixed that the quality of health services represents the source of hospitals' success. Also, it was confirmed that the profitable continuity and reputation of private hospitals are based on the quality of health service which is associated with the most substantial aspect of human life (Health). Additionally, it is considered as the core competence and the mean for sustainable competitive advantage.

Therefore, hospitals are utilizing health service quality to outperform competitors and exceed patients' expectations, to retain current patients, and to attract more of them in the future. Based on the study of Kumar and Chakraborty (2013), Chahal and Mehta (2013), Kaliannan et al. (2016), Yang et al. (2017), Mohammad et al. (2011) and Parand et al. (2014), the above mentioned goals will come true, if hospitals' management work on employees' satisfaction as well as that of patients. This is particularly attributed to the fact that the health service doesn't depend only on employees' skills and their technical capabilities, but also on the employee's willingness to devote more time, efforts, emotions, and care while providing the health service to the patients.

The results of Hughes and Bozionelos (2007), Jamal (2013), Lee et al. (2015), Azeem and Altalhi (2015), Eid (2016), and Yadav et al. (2017) concluded that employees' satisfaction is the key for extraordinary performance and patient's care. However, the results of Peters et al. (2010) and Goodwin and Richards (2017) underlined the significance of supporting health care employees with work life balance actions to boost their satisfaction.

There is a consent that the ability of management to realize and empathize employees sufferings facilitates the adoption of formal work life balance initiatives in health care organizations. Hui-Wen et al. (2010), Salehi et al. (2016), Kumarasamy et al. (2016), Thorat and Dharwadkar (2016), Koubova and Buchko (2013), and Shylaja and Prasad (2017) illustrated that managers EI skills enable them to stand deeply on employees problems, particularly those connected with work life imbalance.

Accordingly, this study's propositions is compatible with the above mentioned studies in terms of the magnitude of managers' Emotional Intelligence (EI) and employees work life balance in work place. Also, it was also consistent with the results of Eid (2016) study which highlighted job satisfaction in Jordanian private hospitals. Mohammad et al. (2011) highlighted the indispensable role of leaders in upholding employees' satisfaction in Jordanian hospitals.

Thus, this study was conducted to examine the degree to which employees in Jordanian private hospitals view their managers which have Emotional Intelligence (EI) abilities and the degree to which hospitals are engaged in WLB activities. The study also tried to test the impact of managers' 
Emotional Intelligence (EI) skills on work life balance initiatives. Finally, the study measured the differences in employees' perception concerning work life balance initiatives due to their gender, marital status, and number of children.

300 employees working at non-managerial levels were involved in the survey, while 286 questionnaires were analyzed. Goleman (1998) employed five (5) dimensions (self-awareness, self-management, self-motivation, empathy and social skills) to measure Emotional Intelligence (EI).

WLB was measured through support activities implemented by health organizations.

The results of the first hypothesis show a positive perception; one sample $t$ test manifested that the surveyed employees consider their managers to possess Emotional Intelligence (EI) abilities. In addition, they are skilled enough to realize and control their feelings and that of their employees, in a way that they create a healthy work environment. These conclusions go with the findings of Bedi and Kaur (2014) and Long et al. (2016). The results of hypothesis 2 confirmed employees' positive perception towards work life balance actions too; they are convinced that Jordanian private hospitals build formal policies to boost their employees' work life balance. It also provides them with the necessary aid to manage roles conflict and job stress.

The results are harmonious with the study of Avgar et al. (2011) and Sharma et al. (2016), in terms of hospitals and management contribution in helping employees to reduce the burden of the multiple responsibilities they have. The results also emphasized the findings of Makabe, et al. (2015) and Pandita and Singhal (2017). They deduced a positive link between work life balance, job satisfaction, and employees' high performance and low level of turnover rate. Meanwhile, the results of the third hypothesis manifested through the value of $\mathrm{F}$ sig (0.000) show that there is a linear relationship between Emotional Intelligence (EI) dimensions and work life balance initiatives. On the other hand, the results of coefficients illustrate a statistically significant impact of just two dimensions of Emotional Intelligence (EI) empathy and social skills on employees work life balance.

The results of this study matched the results of Kumarasamy et al. (2016), Thorat and Dharwadkar (2016), and Shylaja and Prasad (2017). Their study proved the direct connection between Emotional Intelligence (EI) and gaining work life balance, either at the employee or at the management level.

The results of the fourth hypothesis manifest that there is a statistically differences between males and females perception of work life balance initiatives provided by their organizations. Some of the female respondents commented during the survey that Jordanian community's culture imposes on women to play several roles within the family that men are not ready to do, or even to share for just help. At the same time, women are required to do the same efforts and roles within organizations as men. 
The above mentioned results go with the propositions of the previous studies conducted in other countries that females are more interested in work life balance practices. However, they are affected positively more than men in any support strategy provided by organizations. Ciarniene and Vienazindiene (2018) findings pointed that Lithuanian women were more sensitive than men in realizing the depth and benefits of flexible working practices. Emslie and Hunt (2009) confirmed that Scottish women suffer more in their working life than men, and they asked for a broader range of supporting initiatives than males.

Fujimoto et al. (2013) concluded that Australian working women are more interested than men in working life balance strategies. Kakkar and Bhandari (2016) and Doble and Supriya (2010) results disclose that Indian female workers, regardless of their managerial position, are more convenient of work life balance when compared to males. Rehman and Azam (2012) remarked that Pakistanis female entrepreneurs' needs for work life balance activities are more critical than those for men. Padmasiri and Mahalekamge (2016) revealed the same of the female academic staff in Sililanka.

This study also found that there are no differences of respondents' perception of work life balance initiatives provided by their organizations due to their marital status

The results match what Amazue, and Onyishi (2016) inferred that marital status is not a predictor of wok life balance.

Some of the respondents mentioned that even though they are not married, they have responsibilities towards the big family: they are taking care of their old parents or relatives. The same can be inferred when it comes to number of children. Those who are married and don't have children are also devoting part of their time and efforts for their relatives.

Meanwhile, the results didn't go with Jailaxmi and Gautam (2017) results who found an impact of marital status on work life balance. Devi and Sheshadri (2016) also revealed that marital status impact employees ability to get work life balance and their perception of the support practices provided by their organizations.

Thus, the results of the study didn't go with the study of Devi and Sheshadri (2016). They proved a positive relationship between Number of children and the need of work life balance practices within organizations, especially when it comes to flexible working hours and child care faculties.

\section{The Study's Implications}

The study underlined the significance of Work life balance in organizations, and tried to highlight the influence of work life balance on employees' satisfaction as well as on their performance. 
The study also confirmed the magnitude of emotional intelligence in organizations, and the contribution Emotional Intelligence (EI) skills can have in creating balanced work environment.

\section{Recommendations}

Based on the study's results, it is better for private hospitals to have formal work life balance polices that are imbedded in their organizational culture. This would help them to be part of the daily routine activities.

Most of the previous research findings confirmed the value of Emotional Intelligence (EI) skills for employees too and not just for managers. As a result, it was recommended to engage employees in training courses to deepen their knowledge of emotional intelligence and to clarify some details related to understanding the working conditions and the psychological aspects of others. It is also recommended that employees should be taught on how to deal rationally with the difficult working conditions.

It is better to provide employees with training courses that help them to reduce the negative effects of job stress and to teach them how to handle successfully the critical situations they face while working in the hospital.

The researcher recommends giving more attention to working women problems with full understanding of the multiple roles and responsibilities they have. It also provides them with convenient support to alleviate the burdens they suffer.

For future research, other satisfaction factors than work life balance can be taken into consideration. Either in public or private hospitals, work life balance facilitators can be studied in other sectors than the health sector.

\section{Acknowledgement}

The author is grateful to Amman Arab University for the financial support granted for this research.

\section{References:}

1. Alfonso, L., Zenasni, F., Hodzic, S., \& Ripoll, P. (2016). Understanding the mediating role of quality of work life on the relationship between emotional intelligence and organizational citizenship behaviors. Psychological Reports, 118(1), 107-127.

2. Al-khasawneh, A. L., \& Moh, S. (2013). The relationship between job stress and nurses performance in the Jordanian hospitals: A case study in King Abdullah the Founder Hospital. Asian Journal of Business Management, 5(2), 267-275.

3. Amazue, L. O., \& Onyishi, I. E. (2016). Stress coping strategies, perceived organizational support and marital status as predictors of 
work-life balance among Nigerian bank employees. Social Indicators Research, 128(1), 147-159.DOI 10.1007/s11205-015-1023-5

4. Arfara, C., \& Samanta, I. (2016). The impact of emotional intelligence on improving team-working: the case of Public Sector (National Centre for Public Administration and Local GovernmentNCPALG). Procedia-Social and Behavioral Sciences, 230, 167-175.

5. Armstrong, M. (2006). A Handbook of Human Resource Management Practice (10th Edition). London: Kogan Page.

6. Asiamah, N. (2017). Enhancing nurses' emotional intelligence: Are tenure prolongation, education and in-service training applicable methods even when not specialized?.Cogent Business \& Management, 4(1), 1-16.

7. Avgar, A. C., Givan, R. K., \& Liu, M. (2011). A balancing act: Worklife balance and multiple stakeholder outcomes in hospitals. British Journal of Industrial Relations, 49(4), 717-741.

8. Azeem, S. M., \& Altalhi, H. (2015). Role of Perceived Work-life Balance and Job Satisfaction in Developing Organizational Commitment among Hospital Employees in Saudi Arabia. International Journal of Academic Research in Business and Social Sciences, 5(12), 185-197.

9. Bakir, S. M. A. (2017a). The Reality of Applying Human Resources Diversity Management and Its Impact on Workers' (Performance, Cooperation, Commitment and Loyalty): A Field Study on the Jordanian Food Industry Companies. International Business Research, 10(3), 183-192.

10. Bakir, S. M. A. (2017b). The Influence of Strategic Leadership on Building Employees' Entrepreneurial Orientation: A Field Study at the Jordanian Public Sector. International Business Research, 10(6), 6274.

11. Bedi, M., \& Kaur, K. (2014). Emotional Intelligence and Life Satisfaction: An Empirical Study Among Managers in Indian Banking Sector. Amity Global HRM Review, 4. 116-122

12. Borah, N., \& Bagla, N. (2016). Work-Life Balance: Assessing Perceptions. SCMS Journal of Indian Management, 13(3).112-119.

13. Chahal, H., \& Mehta, S. (2013). Developing patient satisfaction construct for public and private health care sectors. Journal of Services Research, 13(2), 7-30.

14. Chiva, R., \& Alegre, J. (2008). Emotional intelligence and job satisfaction: the role of organizational learning capability. Personnel review, 37(6), 680-701.

15. Ciarniene, R., \& Vienazindiene, M. (2018). Flexible Work Arrangements from Generation and Gender Perspectives: Evidence 
from Lithuania. Engineering Economics, 29(1), 84-92. http://dx.doi.org/10.5755/j01.ee.29.1.19247

16. Clarke, N. (2010). Developing emotional intelligence abilities through team-based learning. Human Resource Development Quarterly, 21(2), 119-138.

17. Dabke, D. (2016). Impact of Leader's Emotional Intelligence and Transformational Behavior on Perceived Leadership Effectiveness: A Multiple Source View. Business Perspectives and Research, 4(1), 2740.

18. Daft, R. (2010). Organization Theory and Design, $\left(10^{\text {th }}\right.$ ed), Mason, $\mathrm{OH}$, South-Western Cengage Learning.

19. Daus, C. S., \& Ashkanasy, N. M. (2005). The case for the ability-based model of emotional intelligence in organizational behavior. Journal of Organizational behavior, 26(4), 453-466.

20. Dessler, G. (2014). Fundamentals of human resource management. (3rd ed.) Harlow, Pearson Education Limited.

21. Devi, A. C \& Sheshadri, P. (2016) .The Influence of Demographic Variables on Work Life Balance. International Journal of Economic research, 13(4), 1283-1291

22. Doble, N., \& Supriya, M. V. (2010). Gender Differences in the Perception of Work-Life Balance. Managing Global Transitions: International Research Journal, 8(4). 5 (4): 331-342.

23. Eid, M. T. I. (2016). Highlighting the main factors of job satisfaction among Jordanian hospitals employees .Journal of Applied Quantitative Methods, 11(1). 15-25.

24. Emslie, C., \& Hunt, K. (2009). 'Live to work'or 'work to live'? A qualitative study of gender and work-life balance among men and women in mid-life. Gender, Work \& Organization, 16(1), 151-172. https://doi.org/10.1111/j.1468-0432.2008.00434.x

25. Fowlie, J., \& Wood, M. (2009). The emotional impact of leaders' behaviours. Journal of European Industrial Training, 33(6), 559-572.

26. Fujimoto, Y., Azmat, F., \& Härtel, C. E. (2013). Gender perceptions of work-life balance: Management implications for full-time employees in Australia. Australian Journal of Management, 38(1), 147-170. DOI: 10.1177/0312896212449828

27. Ghosh, R., Shuck, B., \& Petrosko, J. (2012). Emotional intelligence and organizational learning in work teams. Journal of Management Development, 31(6), 603-619.

28. Gibson et al. (2012). Organizations: Behavior, Structure, Processes, (14th Ed.), New ork, Mcgraw Hill Irwin.

29. Goodwin, M., \& Richards, K. (2017). Best practices in healthcare management begin with self. Nursing Economic\$,35(3), 152-155. 
30. Gupta, S. (2014). Research Paper on Emotional Intelligence and Work Life Balance of Employees in the Information Technology Industry.19. available at: http://ssrn.com/abstract $=2395216$

31. Haar, J. M., Russo, M., Suñe, A., \& Ollier-Malaterre, A. (2014). Outcomes of work-life balance on job satisfaction, life satisfaction and mental health: A study across seven cultures. Journal of Vocational Behavior, 85(3), 361-373.

32. Hopkins, M. M., \& Yonker, R. D. (2015). Managing conflict with emotional intelligence: Abilities that make a difference. Journal of Management Development, 34(2), 226-244.

33. Hughes, J., \& Bozionelos, N. (2007). Work-life balance as source of job dissatisfaction and withdrawal attitudes: An exploratory study on the views of male workers. Personnel Review, 36(1), 145-154.

34. Hui-Wen, V. T., Mu-Shang, Y., \& Nelson, D. B. (2010). The relationship between emotional intelligence and leadership practices. Journal of Managerial Psychology, 25(8), 899-926.

35. Jailaxmi \& Gautam A. (2017) Work Life Balance of Bank Employees as Related to Age,

36. Gender and Marital Status, International al Journal of Management \& Business Studies, 7 (1) , 44-46.

37. Jamal, M. (2013). Job stress among hospital employees in middle east: Social support and type a behavior as moderators. Middle East Journal of Business, 8(3), 7-16.

38. Jiang, Z. (2014). Emotional intelligence and career decision-making self-efficacy: national and gender differences. Journal of Employment Counseling, 51(3), 112-124.

39. Kakkar, J., \& Bhandari, A. (2016). A Study on Work-Life Balance in the Indian Service Sector from a Gender Perspective. IUP Journal of Organizational Behavior, 15(1), 1-19.

40. Kaliannan, M., Perumal, K., \& Dorasamy, M. (2016). Developing a work-life balance model towards improving job satisfaction among medical doctors across different generations. The Journal of Developing Areas, 50(5), 343-351.

41. Khan, S. A., \& Agha, K. (2013). Dynamics of the work life balance at the firm level: Issues and challenges. Journal of management policy and practice, 14(4), 103-114.

42. Kim, H. K. (2014). Work-life balance and employees' performance: The mediating role of affective commitment. Global Business and Management Research, 6(1), 37-51.

43. Koubova, V., \& Buchko, A. A. (2013). Life-work balance: Emotional intelligence as a crucial component of achieving both personal life and work performance. Management Research Review, 36(7), 700-719. 
44. Kumar, H., \& Chakraborty, S. K. (2013). Work life balance (WLB): A key to organizational efficacy. Prin. LN Welingkar Institute of Management Development \& Research, 15(1), 62-70.

45. Kumarasamy, M. M., Pangil, F., \& Mohd Isa, M. F. (2016). The effect of emotional intelligence on police officers' work-life balance: The moderating role of organizational support. International Journal of Police Science \& Management, 18(3), 184-194.

46. Latif, M. S., Ahmad, M., Qasim, M., Mushtaq, M., Ferdoos, A., \& Naeem, H. (2013). Impact of employee's job satisfaction on organizational performance. European journal of business and management, 5(5), 166-171.

47. Lakshmi, K. S., Ramachandran, T., \& Boohene, D. (2012). Analysis of work life balance of female nurses in hospitals-comparative study between government and private hospital in Chennai, TN., India. International Journal of Trade, Economics and Finance, 3(3), 213-218.

48. Lam, C. S., \& O'Higgins, E. R. (2012). Enhancing employee outcomes: The interrelated influences of managers' emotional intelligence and leadership style.Leadership and Organization Development Journal, 33(2), 149-174.

49. Lee, J. S., Back, K. J., \& Chan, E. S. (2015). Quality of work life and job satisfaction among frontline hotel employees: A self-determination and need satisfaction theory approach. International Journal of Contemporary Hospitality Management,27(5), 768-789.

50. Locke, E. (Ed.). (2009). Handbook of principles of organizational behavior: Indispensable knowledge for evidence-based management. ( $2^{\text {nd }}$ Ed..), Chi Chester, John Wiley \& Sons.

51. Long, C. S., Yaacob, M., \& Chuen, T. W. (2016). The Impact of Emotional Intelligence on Job Satisfaction among Teachers. International Journal of Management, Accounting and Economics, 3(8), 544-552.

52. Luthans, F., (2012). Organizational behavior: An evidence based approach, (12th ed.). New York, NY: McGraw-Hill Irwin.

53. Makabe, S., Takagai, J., Asanuma, Y., Ohtomo, K., \& Kimura, Y. (2015). Impact of work-life imbalance on job satisfaction and quality of life among hospital nurses in Japan. Industrial health, 53(2):152159.

54. Mathur, A., Purohit, A. and Mathur, R. (2013) "Comparative Analysis of Overall Work Life Balance of Medical Professionals", International Journal of Management Research and Development, 3(2), 94-102. 
55. McCleskey, J. (2014). Emotional intelligence and leadership: A review of the progress, controversy, and criticism.International Journal of Organizational Analysis, 22(1), 76-93.

56. McKeown, A., \& Bates, J. (2013). Emotional intelligent leadership: Findings from a study of public library branch managers in Northern Ireland. Library Management, 34(6/7), 462-485.

57. Mohammad, S. I. S., Al-Zeaud, H. A., \& Batayneh, A. M. E. B. (2011). The relationship between transformational leadership and employees' satisfaction at Jordanian private hospitals. Business and Economic Horizons, 5(2), 35-46.

58. Mudra, L. (2016). Employees' Perception of Work Life Balance Practices: A Study in an IT Company, Bhubaneswar. Vilakshan, XIMB Journal of Management, 14 (1), 101-109.

59. Nathans, L. L., Oswald, F. L., \& Nimon, K. (2012). Interpreting multiple linear regression: A guidebook of variable importance. Practical assessment, research \& evaluation, 17(9), 1-19.

60. Pandita, S., \& Singhal, R. (2017). The Influence of Employee Engagement on the Work-Life Balance of Employees in the IT Sector. IUP Journal of Organizational Behavior, 16(1), 38-57.

61. Padmasiri, M. K. D., \& Mahalekamge, W. G. S. (2016). Impact of Demographical Factors on Work Life Balance Among Academic Staff of University of Kelaniya, Sri Lanka. Journal of Education and Vocational Research, 7(1), 54-59.

62. Parand, A., Dopson, S., Renz, A., \& Vincent, C. (2014). The role of hospital managers in quality and patient safety: a systematic review. BMJ open,4(9), 1-15, http:// doi:10.1136/bmjopen-2014005055

63. Peters, D. H., Chakraborty, S., Mahapatra, P., \& Steinhardt, L. (2010). Job satisfaction and motivation of health workers in public and private sectors: cross-sectional analysis from two Indian states. Human resources for health, 8(1), 27.

64. Poulose, S., \& Sudarsan, N. (2017). Assessing the influence of worklife balance dimensions among nurses in the healthcare sector. Journal of Management Development, 36(3), 427-437.

65. Rama Devi, V., \& Nagini, A. (2014). Work-life balance and burnout as predictors of job satisfaction in private banking sector. 4 (1) 50-53.

66. Rehman, S., \& Azam Roomi, M. (2012). Gender and work-life balance: a phenomenological study of women entrepreneurs in Pakistan. Journal of Small Business and Enterprise Development, 19(2), 209-228. http://dx.doi.org/10.1108/14626001211223865 
67. Robbins, S. P., \& Judge, T. A. (2013), Organizational behavior (15th ed.). Boston, Pearson Prentice-Hall.

68. Saima, S., \& Zohair, M. (2016). Understanding Work-Life Balance with Respect to Medical Practitioners: A Conceptual Framework. IUP Journal of Organizational Behavior, 15(4), 66-75.

69. Salehi, M., Zadeh, M. A., Ghaderi, A., \& Tabasi, A. Z. (2016). Study of the Effect of Education and Academic Environment on Emotional Intelligence on Accounting Students in Iran. International Education Studies, 9(1), 182-188.

70. Santos, A., Mustafa, M. J., \& Gwi, T. C. (2015). Trait emotional intelligence, emotional labor, and burnout among Malaysian HR professionals. Management Research Review, 38(1), 67-88.

71. Sekaran, U. (2003)Research methods for business: A skill building approach (4 th ed.). New York, NY. John Wiley \& Sons.

72. Shafiq, M., \& RANA, R. A. (2016). Relationship of Emotional Intelligence to Organizational Commitment of College Teachers in Pakistan. Eurasian Journal of Educational Research, 16(62).1-14.

73. Sharma, L. N. (2014). Emotional Intelligence as Corelate to Work Life Balance (A Case Study of Sidhi MP). Global Journal of Finance and Management, 6(6), 551-556.

74. Saunders, M., Lewis, P., \& Thornhill, A. (2013). Research methods for business students, $6^{\text {th }}$ Ed.. Harlow, Pearson education.

75. Sharma, S., Parmar, J. S., \& Chauhan, S. S. (2016). Work-related Variables and Work-Life Balance-A Study of Nurses in Government Hospitals of Himachal Pradesh. Productivity, 57(3), 286- 292.

76. Shylaja, P. \& Prasad, Ch. J. (2017). Emotional Intelligence and Work Life Balance.

77. IOSR Journal of Business and Management 19 (5), 18-21.

78. Srividhya, S. \& Sharmila, G. (2014). "A study on importance of Emotional Intelligence in Work Life Balance of Women Employees". GALAXY International Interdisciplinary Research Journal,.2 (4), 118123.

79. Stubbs Koman, E., \& Wolff, S. B. (2008). Emotional intelligence competencies in the team and team leader: A multi-level examination of the impact of emotional intelligence on team performance. Journal of Management Development, 27(1), 55-75.

80. Tang, C., \& Gao, Y. (2012). "Intra-department communication and employees' reaction to organizational change: The moderating effect of emotional intelligence." Journal of Chinese Human Resources Management, 3(2), 100-117. 
81. Tanushree. (2013). 'Focusing on Employee Work Life Balance: A Study of Gas Authority of India Ltd', Global Journal of Commerce \& Management Perspective, 2(1), 47-49.

82. Thorat, P. \& Dharwadkar, K. ( 2016) Role of Emotional Intelligence in managing Work-life Balance with special reference to Bank employees in Mumbai City, International J. Res, 5(2), 24-27.

83. Torrington D., Hall, L., Taylor, S., \& Atkinson, C (2011), Human Resource Management, $\left({ }^{\text {th }} \mathrm{ed}\right.$.), Harlow, Pearson Education Limited.

84. Wheelen, T. L. \& Hunger, D (2012) Strategic Management and Business Policy: Toward Global Sustainability $13^{\text {th }}$ Ed. Boston, Pearson Education, Inc.,

85. Yadav, R., Srivastava, D. K., Yadav, S., Kumar, S., Jain, P. K., \& Gupta, S. (2017). Job satisfaction and Job stress among various employees of tertiary care level hospital in central Uttar Pradesh, India. Indian Journal of Community Health, 29(1), 67-74.

86. Yang, S., Liu, D., Liu, H., Zhang, J., \& Duan, Z. (2017). Relationship of work-family conflict, self-reported social support and job satisfaction to burnout syndrome among medical workers in southwest China: A cross-sectional study. PloS one, 12(2), 1-12.

87. Zhang, S. J., Chen, Y. Q., \& Sun, H. (2015). Emotional intelligence, conflict management styles, and innovation performance: An empirical study of Chinese employees. International Journal of Conflict Management, 26(4), 450-478.

88. Zikmund, W.G (2003) Business Research Methods , $7^{\text {th }}$ Ed, Mason" Thomson Learning. 